\title{
Militia Participation in Counterinsurgency: The Impetus of Civilian Joint Task Participation in Combating Boko Haram in Nigeria
}

\author{
M.L. Gana \\ Mai Idriss Alooma Polytechnic Geidam \\ 1023 Gashua Road Geidam, Yobe State, Nigeria
}

\begin{abstract}
Since 2013, the north of Nigeria has witnessed an increased involvement of the militia group 'Civilian Joint Task Force' (CJTF) in combating the Islamist insurgent group Boko Haram. The mobilization of the Civilian Joint Task Force brought a tremendous success to the counterinsurgency operation. Before the CJTF's engagement, the antiterrorism efforts of the government were marred by negligent performance. In addition to helping decrease the attack frequencies and number of fatalities caused by the insurgent group, the militia succeeded in expelling Boko Haram fighters from the towns and villages they had previously occupied. However, the unprecedented participation of the Civilian Joint Task Force in the counterinsurgency campaign has raised certain suspicions of the public in regards to the CJTF's ulterior motives. This paper, therefore, explores the motives that triggered people's participation in the Civilian Joint Task Force with the aim to combat the Boko Haram insurgent group. The current paper is a qualitative research, designed as a case study. The empirical data were collected by means of an in-depth interview involving 13 respondents, among who were the members of the CJTF, community leaders and government officials in Yobe State, Nigeria. The findings show that people's participation in the CJTF is voluntary, with the main motivation being the necessity to defend the community due to the state's failure to provide adequate protection. The article points out an urgent need to demobilize and deradicalize the participants in order to prevent the CJTF from further jeopardizing local communities' peace and stability.
\end{abstract}

Keywords: Civilian Joint Task Force, counterinsurgency, Boko Haram, security

\section{Introduction}

Since 2013, Nigeria's counterinsurgency campaign against the Islamist Insurgent group Boko Haram has witnessed an unprecedented support from civil militia, colloquially known as the 'Civilian Joint Task Force' (CJTF). Dubbed after the conventional 'State Special Joint Task Force' and the 'Multinational Joint Task Force', the CJTF was established by the member states of the Lake Chad Basin Commission. Surprisingly, despite the abysmal performance of the state counterinsurgency response, the participation of the Civilian Joint Task Force proved to be a substantial contribution to the combating activities. The militia's participation was crucial in eliminating the insurgent group and reconquering several towns and villages occupied by Boko Haram, including Maiduguri, the spiritual home of the insurgents [1; 2]. Moreover, CJTF was also contri-

\section{Gana M.L., 2019.}

This work is licensed under a Creative Commons Attribution 4.0 International License https://creativecommons.org/licenses/by/4.0/ 
butory in terminating hundreds of Boko Haram fighters, as well as rescuing thousands of people held in captivity by the insurgent group. In March 2014, for instance, the CJTF members freed nearly 5,000 people in the town of Mafa, located in the rebellious Borno State, about $30 \mathrm{~km}$ from the capital city of Maiduguri [2]. Besides protecting the civilian population, CJTF was instrumental in abating attacks launched on Nigeria's security operatives. In this respect, it is noteworthy to mention the courageous role of the group in repelling an attack on the notorious Giwa barrack in Maiduguri. Boko Haram had nearly overrun the military formation forcing the troops to withdraw from the battlefront; however, the rapid mobilization of CJTF rendered a huge blow to Boko Haram, capturing several arms, including an armored personnel carrier. Commemorating the success of CJTF, Nigeria's former President Good Luck Jonathan referred to the CJTF members as to Nigeria's new national heroes.

Subsequently, continued resistance of the group, as well as enrollment of new members in spite of the costly risk, has raised public concern, and the group was accused of having "different motivations". For instance, by some accounts, nearly 600 members of the CJTF were brutally murdered by Boko Haram fighters [2]. However, the increasing fatalities have not deterred the 'vigilantes' from further participation in the military activities, which raised certain doubts about the group's true intentions. Nevertheless, until recently, the militants' underlying motives have not been a topic of scientific research. The given study, therefore, deems it important to address the issue. The article is made up of five sections. Section one describes the methodology of the study, section two presents an overview of the Boko Haram insurgency, section three explores the origin of the CJTF, section four explains the group's ulterior motivation. Finally, section five sums up the results of the study into a conclusion and gives recommendations.

\section{Methodology}

The current work is a qualitative research, designed as a case study. The empirical data were collected by means of an in-depth interview involving 13 respondents, among who were the members of the CJTF and community leaders in Yobe State, Nigeria. The presence of militia and inaccessibility of the other state due to the terrifying insurgency situation impeded empirical data collection. The interview data were backed up by field observation. The research covers the period between February and April 2018. The selection of the participants is based upon knowledge of the subject, familiarity with CJTF practices and personal experiences, as well as on the willingness of a respondent to participate. On average, each interview lasted for approximately 50 minutes, with slight variations depending on the availability of the informant. In compliance with ethical principles, each interviewee was at liberty to choose the time and place of the interview. Moreover, to ensure the voluntariness of participation, the examiner offered each informant to sign a consent form. The researcher also guaranteed confidentiality of the information to the participants as well as a right to withdraw it at any stage of the research process. To ensure the anonymity of the informants, three assumed names (A, B, and C) were used to represent different categories of the informants. The credibility of the study is secured through extensive triangulation of the data, consultations with experts and peer reviews. 


\section{Boko Haram Insurgency in Nigeria}

Boko Haram is a Muslim group following the Sunni denomination of Islam (particularly, its Salafi-Wahhabi variation) in northern Nigeria. The name Boko Haram literally means 'Western education is a sacrilege'. The official name of the movement is Jama 'atu Ahli is-Sunnah lid-Da 'wati wall-Jihäd or, literally, 'People Committed to the Propagation of Prophet's Teaching and Jihad' [3]. According to certain evidence, the group was founded by Malam Mohammed Yusuf, a radical Salafist scholar, in the metropolitan town of Maiduguri, the capital of Borno state, Nigeria. Mohammed Yusuf was born in 1970 in Yobe state, where the violent teaching of Ibn Tayyamiya, a $13^{\text {th }}$-century theologian from Syria, is openly indoctrinated. During its early years, the group was designated to become the "Nigerian Taliban". Some followers, however, called themselves 'Yusufiya', after the name of the group's founding leader Mohammed Yusuf. During its earlier years, Boko Haram operated using nonviolent tactics. The groups' strategies were based Mahatma Gandhi's idea of nonbelligerent resistance: withdrawal from society, defiance of authorities, and deliberate violation of current laws of the state. At the time, the activities of the group were concentrated in the city of Maiduguri, however, it operated numerous cells in other cities and towns such as Damaturu, Bauchi, Kano, Kogi, and Potiskum in the north of Nigeria. There were minimal accounts of violent outbreaks in most of these cities until in the year 2009.

The only record of the groups' skirmishes before 2009 was an episode in Kanamma, a border settlement in Yobe state, when some disgruntled members of the insurgent group withdrew to practice conventional lives, recruit members, and train fighters [1]. In Kanamma, to obtain people's acceptance and support, the insurgents offered the local population free access to the farmland and fishing pond that they had purchased in the area. The people-oriented approach of the group won it massive popular support and recognition [4]. However, to solve a dispute over the farmlands and fishing rights with some local authority officers, Boko Haram resorted to violence. The efforts of the police to resolve the situation exacerbated it even further, which resulted in the local police force being overpowered by Boko Haram militants. The insurgents torched several public structures including the police building, local authority offices, and the local monarch's palace [4]. It is a popular belief that the looting of the police armory emboldened the militants and served as an impetus for the beginning of the group's violent campaign.

Although, while Boko Haram's activities ebbed over the years, the insurgent threat came to global notice in July 2009 when the militants embarked on a one-week anti-government and anti-west uprising in the cities of Maiduguri, Bauchi, and Kano. The uprising, the death toll of which, according to some sources, amounted to approximately 1000 victims [5; 6], among whom were Mohammed Yusuf, Baba Fugu and Buji Foi, was included in the top most catastrophic incidents since 1970 [2; 7]. Yusuf died under suspicious circumstances while in police custody [6]. Accused of brutal execution of the sect leader, the Nigerian police authorities, however, denied the charge on multiple occasions. After the death of Boko Haram's founder, Abubakar Shekau, 
a former deputy to Yusuf, assumed the leadership of the group. Under Shekau's command, Boko Haram's radicalization increased, the attacks became more brutal and frequent, as the number of fatalities grew. For instance, in addition to the traditional methods of arson, assault, and pillage, Boko Haram adopted some "advanced" terrorist practices, such as employing improvised explosive devices [IEDs]. As the group's attacks were becoming increasingly sophisticated (other new methods included kidnapping and ambush operations), the group's violence expanded into other cities, including Abuja, the capital city of Nigeria. Notable examples of aggression in Abuja include the detonation of a vehicle-borne improvised explosive device [VBEID] targeted at the Police General office, and an attack at the United Nations headquarters in August 2011, which left nearly 30 people dead and over 80 injured [5].

Subsequently, the most brutal of Boko Haram's attacks happened in August 2014, when the militants invaded several towns and villages in northeast Nigeria. On $26 \mathrm{Au}-$ gust 2014, Boko Haram infiltrated into the town of Gwoza, shooting sporadically, capturing and slaughtering much of the local population [8; 9]. Abubakar Shekau, in fact, designated the town to be Boko Haram's administrative city. By the end of 2014, the territory seized and controlled by Boko Haram was approximately $20,000-\mathrm{km}^{2}$, covering 67 local government councils [1;9;10-12]. Disturbingly, in spite of successive counterinsurgency measures initiated by the government, the number of Boko Haram's victims and the degree of material destruction inflicted by the terrorists kept escalating [13]. It was not until the community group "Civilian Joint Task Force" got involved in combating the terrorist activities of Boko Haram that insurgent fatalities began to subside.

\section{Civilian Joint Task Force: History Overview}

Some accounts attribute the origin of CJTF to the courageous work of Baba Lawal Jaafar of Hausari's ward in Maiduguri, the capital city of Borno state [1; 2]. Lawal, according to the sources, accosted an armed Boko Haram fighter, fully strapped with rounds of ammunition, arrested him and delivered to the nearest security formation. The courageous work of Lawal inspired the local population, particularly the youth, which, according to some sources, comprises nearly $70 \%$ of the CJTF participants [14]. Civilian members of local communities mobilized to counter the security threat presented by Boko Haram. Within the shortest time period, the CJTF's activities spread to other states and towns affected by the insurgency. At the initial stage, the group's modus operandi was mostly neighborhood watch, namely, patrolling streets in the night and mounting roadblocks at certain strategic locations. With the aid of sticks, cutlasses, bows and arrows, the CJTF members successfully combatted Boko Haram fighters and collaborators.

Eventually, the tremendous success of the CJTF impressed the state authorities, which, although initially critical of its operation, ended up providing legislative support to the self-formed militia. The CJTF was also regimented into sector squads. In Borno state, for example, the movement was classified into groups 'Borno Youths Em- 
powerment Scheme' (BOYES) and 'Youth Vanguard'. The Borno State government offered logistic support in the form of 60 patrol trucks to the civilian JTF. In Yobe state, the movement was named 'Peace Group', and in Adamawa state, 'Sarkin Baka' (literally, 'hunters' force'). With the support from the government, the CJTF members have been increasingly successful in quelling the insurgent activities. Despite the importance of CJTF's contribution in battling Boko Haram, the factors that triggered the formation of the group and the reasons that account for the community members' eager participation in its activities have not been sufficiently analyzed. The following subsection looks into possible underlying motives of people's participation in CJTF.

\section{The Motivation of Civilian Joint Task Force Members}

According to the empirical data collected, the loss of faith in the institutional power and the ability of the state to protect its people, predetermined the formation of the CJTF group. In fact, despite the compelling evidence that Nigeria's government massively deployed its armed securities numbering over 100,000 [8], the majority of the informants claimed they felt unsafe, unprotected and exposed to the cruel violence of the insurgent group Boko Haram. Therefore, due to the discontent with the performance of state security operatives in combating the insurgents, people united in the Civilian Joint Task Force for self-defense. According to the majority of the respondents, the participation of people in CJTF was primarily instigated by the necessity of the communities to defend themselves against the rampaging violence of the Boko Haram group. The fundamental objective of CJFT, as was pointed out by the informants, was to compensate for the failure of the state authorities to protect the lives and ensure security of the civilian population terrorized by Boko Haram militants.

Our interest is to defend our people. Every day we live in fear, sleep in fear and wake-up in fear. To be precise, we have lost hope in the ability of the state security operatives to ensure our protection. Therefore, we mobilized to defend families, ourselves, and other community people (informant A1).

The statement above also conforms to the fact that CJTF is mainly a communitybased group whose activity is generally localized. It is a volunteer force that operates in neighboring living areas and advocates the necessity of a joint effort in fighting the Boko Haram menace. The citizen-driven communal participation is aimed at tackling and preventing insurgent activities and bringing long-lasting solutions to the security challenge in the country. The statement of informant A2 supports this assertion:

We cannot go to the market; our children are not going to school and people stop attending even the congressional prayers because of the unforeseen. Therefore, we realize that if the insurgency situation persists, we all are doomed (informant A2).

The informants' testimony suggests that the primary objective of CJTF is to secure their communities and restore socioeconomic activities of the local population. Thus, the respondents' statements concur with the suggestion that CJTF emerged in response to the state's failure to counter the insurgent threat. Such local vigilante groups often appear when there is a lack of people's trust and confidence in the performance of 
the state. According to [2], CJTF is an incredible tool, a community-based security option, a model built on a proactive citizen-driven communal response. The testimony of informant A5 confirms this definition:

"...our job is to combat the insurgent group Boko Haram and defend ourselves and local people from their atrocities. We are all members of the community. We have no motive other than defending our people. We have not recruited any gang members, all of us are law-abiding citizens".

Thus, the cardinal factor that influences people's desire to join CJTF is the failure of the sovereign state to ensure the protection of the lives and valuable resource of its citizens. The finding is confirmed by Fearon and Laitin [15], who claim that militias participate in security activities when there is a pervasive weakness of the State. Concurrently, Humphrey and Weinstein in their analysis of the factors contributing to the mobilization of civil population shows that nearly $51 \%$ of people participate in militias because of the inability of the sovereign state to secure the lives and properties of the people. Stringham \& Forney [16] highlight a similar factor in regards to the activities of the White Army Militia in South Sudan. The factors triggering the formation of CJTF are also consistent with those that caused the emergence of the Kamajor militia in Sierra Leone in the aftermath of the country's civil war.

More examples of militias that have been formed on the basis of the same rationale as CJTF include: the Bakassi boys in the southeast region, Oduduwa People Congress [OPC] in the southwest, and ECOMOG in the northern region. Although most of these groups have certain ethno-cultural and religious divergences, as well as different tactics, the feature that unites them all is their commitment to defend their communities against violence and insecurity. According to the theory of social science, every sovereign state bears responsibility to protect the security of its citizens and provide safe environment for the lawful pursuit of livelihood. The state has the authority to settle disputes and enforce law and order using armed forces and civil police force. In return, the citizens pledge to abide by the existing laws of the state. However, if the citizens feel discontent, either genuine or presumed, with the way the state carries out its obligations, they assume the functions of the state to protect their communities. They take law into their own hands, neutralizing suspected robbers, guarding markets and engaging in neighborhood watches. In Nigeria, these groups are rampant not only in places where the government fails to provide security, but also in areas where the government is perceived to be untrustworthy. CJTF serves as a perfect example to illustrate this case.

However, whereas the previous studies have shown that the CJTF proved to be very successful in stopping Boko Haram's attacks through their vigilante activities, our research revealed numerous flaws of the group. Firstly, its practices contradict the Weberian principles of state autonomy. According to Marx Weber, a 19th-century German philosopher, the State is the sole and absolute authority possessing the monopoly of controlling violence on its territory. Thus, the participation of the CJTF in the security function of the state infringes this principle. Nigerian state authorities acknowledged this fact: 'It is illegal, but looking at the situation we found ourselves in, we appreciate 
their courage and rejoice at their success' (Informant B3). Other informants, on the contrary, claimed that some of the CJTF participants act as informers and collaborators to Boko Haram. This accusation is partially based on the fact that currently government forces insist on taking part in CJTF's counterinsurgency operations. As was narrated by informant C3 [a community leader], 'there is fear that they are leaking information to Boko Haram. You can see nowadays that the government has banned them from going to operate on their own, without the state military involved.' In this regard, CJTF is becoming a potential obstacle on the way to complete termination of the insurgency. Prevailing evidence suggests that with the massive support of the local population, CJTF is likely to eliminate the vestiges of the sovereign state. Consequently, the overall effect from CJTF's activities only exacerbates the conflict they intended to settle. The findings of the given study, therefore, support [2], who points out that CJTF has challenged the rule of law and the monopoly of the state to control violence in different ways, including violation of citizen's rights and freedom. Apart from studies devoted to CJTF's role in resistance to insurgency, the consequences of militia involvement in security operations have previously been studied in numerous works. One of the studies indicates that militia often exceeds its duties by abusing human rights, extorting civilians, and sabotaging peace deals in order to extend the period of their tenure [17].

\section{Conclusion}

The given case study has revealed that Civilian Joint Task Force is a communitybased defense group that emerged in response to the inadequate protection provided by the state [18]. According to Schubert [19], such groups are formed to fill the gaps in the poor performance of the state, failing to protect its citizens at the times of fullblown protracted conflicts. The data revealed that the ineffectiveness of the state in initiating necessary counterinsurgency measures to ensure protection from the heinous crimes of Boko Haram appeared to be the main motivation for people's participation in the CJTF group. However, despite the remarkable success of its activities, there is a growing fear that the group is using its power to abuse the civil population. CJTF's continued engagement constitutes a direct threat to the stability of the locals, as they are turning into a security menace to the state and the nation in general. Following from the above, the article suggests the following steps should be taken:

1. There is an urgent need for the demobilization of the group. Moreover, the demobilized participants should be de-radicalized through extensive training and advising preferably managed by an institution of higher education.

2. Since the number of victims attributed to the Boko Haram insurgency is increasing, while the state is failing to provide necessary protection to the civilian population, which in turn causes people to join CJTF, the government should adopt effective security measures targeting the insurgent fighters.

3. It is also essential to introduce administrative measures to assist the local population with their difficulties, thus eroding the support base among the population toward the insurgents. 


\section{REFERENCES}

[1] Agbiboa D. Resistance to Boko Haram: Civilian Joint Task Forces in North-Eastern Nigeria Conflict Studies Quarterly. Conflict Studies Quarterly. 2015: 3-22.

[2] Bamidele O. Civilian Joint Task Force' (CJTF) - A Community Security Option: A Comprehensive and Proactive Strategy to Counter-Terrorism. Journal for Deradicalization. 2016; Vol. 7: 124-144.

[3] Salaam A.O. Boko Haram: Beyond Religious Fanaticism. Journal of Policing, Intelligence and Counter Terrorism. 2012; Vol. 7; 2: 147-162.

[4] Aghedo I., Osumah. O. The Boko Haram Uprising: How Should Nigeria Respond? Third World Quarterly. 2012; Vol. 33 (5): 853-869.

[5] Pham J-P. Boko Haram's Evolving Threat. Africa Security Brief: A Publication of the Africa Center for Strategic Studies. 2012; 20: 1-7.

[6] Shola O.J. Globalization of Terrorism: A Case Study of Boko-Haram in Nigeria. International Journal of Politics and Good Governance. 2015; Vol. 6.1: 1-22.

[7] Muhammad A., Baba I.M. Resolving Nigeria's "Boko Haram" Insurgence: What Role for the Media? Procedia - Social and Behavioural Sciences. 2014: 155.

[8] Falode J.A. The Nature of Nigeria's Boko Haram War, 2010-2015: A Strategic Analysis. Perspectives on Terrorism. 2016; Vol. 10.1: 41-52.

[9] Oyewole S. Boko Haram and the Challenges of Nigeria's War on Terror. Defence \& Security Analysis. 2013; Vol. 29 (3): 253-262.

[10] Bappah H.Y. Nigeria's Military Failure Against the Boko Haram Insurgency. African Security Review. 2016; Vol. 25; 2: 146-158.

[11] Gana M.L., Samsu K.H., Ismail M.M. Population-Centric Counterinsurgency: The Conduit for Ending Boko Haram Insurgency in Nigeria's North. European Journal of Behavioral Sciences. 2018; 1 (4): 8-13.

[12] Gana M.L., Samsu K.H., Ismail M.M. Counterinsurgency Responses in Nigeria: Unveiling the Constraining Challenges. International Journal of Arts, Humanities and Social Sciences. 2018. Vol. 3.6: 1 -8.

[13] Fahim S. The Role of Militias in Counterinsurgency Doctrine: The Fall of Kunduz and Mosul. Master's Thesis submitted to Department of International Studies, Indiana University; 2018.

[14] Hassan I., Pieri Z. The Rise and Risks of Nigeria's Civilian Joint Task Force: Implications for Post-Conflict Recovery in Northeastern Nigeria. Boko Haram beyond the Headlines: Analyses of Africa's Enduring Insurgency. Jacob Zenn Eds. Combating Terrorism Center; 2018.

[15] Fearon J.D., Laitin D.D. Ethnicity, Insurgency, and Civil War. American Political Science Review. 2003; Vol. 97.1: 75-90.

[16] Stringham N., Forney J. It Takes a Village to Raise a Militia: Local Politics, The Nuer White Army, and South Sudan's Civil Wars. Journal of Modern African Studies. 2017; Vol. 55.2: $177-199$.

[17] Jones S.G. The Strategic Logic of Militia. National Defence Research Institute Working Paper, WR-913-SOCOM. 2012.

[18] Olanrewaju F.O., Folarin O.M., Folarin S.F. Insurgency and National Security Challenges in Nigeria: An Introductory Analysis. Ante Portas - Studia nad Bezpieczeństwem. 2017; Vol. 2.9: $35-53$.

[19] Schubert M. The Challenge of Community-Based Armed Groups: Towards a Conceptualization of Militias, Gangs, and Vigilantes. Contemporary Security Policy. 2015; Vol. 36.2: 296-320.

\section{Article history:}

The article was submitted on 27.05.2019.

The article was accepted on 28.06.2019. 


\title{
Участие ополченцев в антиповстанческой борьбе: роль гражданских подразделений совместного действия (CJTF) в борьбе с Боко Харам в Нигерии
}

\author{
М.Л. Гана \\ Политехнический колледж Маи Идрисс Алума Гейдам \\ 1023 Гамуа Род Гейдам, итат Йобе, Нигерия
}

\begin{abstract}
Аннотация. С 2013 года на севере Нигерии наблюдалось массовое участие ополченцев группы «Гражданская совместная целевая группа» (CJTF) для оказания помощи правительственным силам в борьбе с исламистской повстанческой группировкой «Боко Харам». Мобилизация гражданской совместной оперативной группы принесла огромный успех операции по борьбе с повстанцами. Автор утверждает, что до того момента, когда в борьбу с экстремистами вступили представители CJTF, усилия правительства по борьбе с повстанцами являлись в целом недостаточно эффективными и успешными. Рассматриваемая в статье гражданская группа, помимо оказания помощи и снижения частоты нападений «Боко Харам» и обусловленной ими гибели людей, играет также важную роль в изгнании повстанцев из районов страны, участвует в освобождении городов и деревень, занятых боевиками. Однако беспрецедентное участие гражданской совместной целевой группы в антиповстанческой борьбе породило у нигерийской общественности и политологов подозрения в том, что это участие было обусловлено определенными политическими мотивами. В настоящей статье рассматриваются мотивы, побудившие население ряда районов Нигерии принять участие в гражданской совместной целевой группе по борьбе с группировкой «Боко Харам». В подготовке статьи автор опирался на качественное проектирование конкретных практических кейсов как на основной метод исследования. Эмпирические данные были собраны в ходе углубленного интервью с участием тринадцати информаторов, включая участников CJTF, лидеров общин и правительственных чиновников штата Йобе. Выводы исследования показывают, что участие людей в СJTF является добровольным. Основной мотивацией для участия, является интерес к защите своего сообщества из-за недостаточной защиты со стороны государства. В статье содержатся рекомендации нигерийскому правительству срочно провести демобилизацию и дерадикализацию членов СJTF, для того чтобы не допустить дальнейшего подрыва мира и стабильности в регионах страны.
\end{abstract}

Ключевые слова: гражданская совместная оперативная группа, борьба с повстанцами, Боко Харам, безопасность

\section{История статьи:}

Статья поступила в редакцию 27.05.2019.

Статья принята к публикации 28.06.2019.

\section{Информация об авторе:}

Гана Моду Лаван - кандидат политических наук, преподаватель Политехнического колледжа Маи Идрисс Алума Гейдам (Нигерия) (ORCID ID: 000-0001-9217-1373) (e-mail: gana.lawan@yahoo.com).

Information about the author:

Gana Modu Lawan - PhD in Political Science, Lecturer of Mai Idriss Alooma Polytechnic Geidam (Nigeria) (ORCID ID: 000-0001-9217-1373) (e-mail: gana.lawan@yahoo.com). 


\section{Для цитирования:}

Gana M.L. Militia Participation in Counterinsurgency: The Impetus of Civilian Joint Task Participation in Combating Boko Haram in Nigeria // Вестник Российского университета дружбы народов. Серия: Политология. 2019. Т. 21. № 3. С. 460-469. DOI: 10.22363/2313-1438-2019-21-3-460-469.

\section{For citation:}

Gana M.L. Militia Participation in Counterinsurgency: The Impetus of Civilian Joint Task Participation in Combating Boko Haram in Nigeria. RUDN Journal of Political Science. 2019; 21 (3): 460-469. DOI: $10.22363 / 2313-1438-2019-21-3-460-469$. 